\title{
Answering Back to Presumed Accusations: Serbian First World War Memories and the Question of Historical Responsibility
}

\author{
Ismar Dedović and Tea Sindbrek Andersen
}

In the autumn of 2013, as the centenary of the First World War was looming in the near future, Tomislav Nikolić, president of Serbia, officially rejected that his country could in any way be held responsible for the beginning of that war. In an open letter published in the distinguished newspaper Politika, Nikolić wrote that voices were heard which tried to redefine the 'Vidovdan assassination', the Serbian phrase for the murder of Franz Ferdinand on 28 June 1914, as a terrorist attack. The aim of this, according to Nikolić, was to declare Serbia a priori guilty. 'Will the victorious powers allow attempts at revising history by the invention of a terrorist attack as the cause for the beginning of the First World War? Are the victims of a righteous battle for freedom in vain?' asked Nikolic, stating that 'We have no right to remain silent even if this lie were represented by one single voice.' ${ }^{\prime}$

The voices mentioned by Nikolić remain undefined and anonymous. Nevertheless, there is no doubt that Nikolić's passionate letter is composed as a response to what is perceived as accusations and attempts to blame Serbia for the beginning of the Great War. After posing his questions, Nikolić moves on to explain what he sees as the causes of the war, positioning them firmly outside Serbia, and to remind his readers of the catastrophic losses and suffering that Serbia endured during the wartime years.

While Nikolićs letter has the appearance of a reaction, the exact origin of the accusation is not mentioned in it. However, in a speech given in June 2014, at the eve of the centenary of the First World War, Nikolic clearly identifies Christopher Clark's book from 2012 The Sleepwalkers. How Europe Went to War in 1914 as the primary source of revisionist attempts to blame Serbia for the

1 Tomislav Nikolić, "budimo dostojni junačke prošlosti," Politika, 10 November 2013, accessed 15 September 2016, http://www.politika.rs/sr/clanak/275423/Budimo-dostojni-junackeproslosti. 
outbreak of the war. ${ }^{2}$ Yet, these statements from Serbia's president are certainly not the first examples of attempts to contradict or reject presumed accusations that Serbia could be held responsible for the outbreak of the First World War. A long tradition of such rejections can be detected nearly all the way through the century since the War began. Thus, while Nikolić's statements constitute a highly politicized reception of, among others, Clarke's book, they are certainly also highly premediated repetitions of an old argument. ${ }^{3}$ Yet, Nikolić is also claiming to protect Serbia's memory of the First World War, a war that cost Serbia very dearly, but also ensured the country's position among the victorious Entente powers and led to the creation of the first Yugoslav state in 1918. Indeed, Nikolićs letter is titled 'Let us be proud of our heroic past'. ${ }^{4}$

This chapter investigates Tomislav Nikolić's statements in connection to the First World War centenary, both as remediation of Serbian memories of the outbreak of the Great War and as reception of Clark's book. We trace what we see as a powerful premediation of Nikolićs statements in the tradition of rejecting Serbia's potential responsibility for the war in history books and school textbooks on history. We argue that this is an essential element of Serbia's war memory. Moreover, we propose that this tradition of rejecting war responsibility could be understood as reception of real and perceived accusations, and we suggest that the urge to stand up to these perceived accusations will render Serbia's First World War memory a certain urgency and a sense that it needs protection, which will increase its actuality and relevance in the present.

\section{Serbia and First World War Memory}

The First World War, Europe's 'great seminal catastrophe' in the words of George Kennan, ${ }^{5}$ is widely and massively commemorated throughout Europe. ${ }^{6}$

2 “Govor Predsednika Republike, SANU - Veliki Rat. 13 June 2014." (A print of the speech was kindly supplied at request from the press centre at the office of the President of the Republic of Serbia).

3 Astrid Erll, "Remembering across Time, Space and Culture: Premediation, Remediation and the 'Indian Mutiny,", in Mediation, Remediation and the Dynamic of Cultural Memory, edited by Astrid Erll and Ann Rigney (Berlin: De Gruyter, 2009), 111.

4 Nikolić, "budimo dostojni junačke prošlosti".

5 George Kennan, The Decline of Bismarck's European Order. Franco-Russian relations, 1875-189o (Pinceton: Princeton University Press, 1979), 3.

6 For example: George L. Mosse, Fallen Soldiers. Reshaping the Memory of the World Wars (Oxford: Oxford University Press, 1990); Jay Winter, Sites of Memory, Sites of Mourning. The Great War in European Cultural History (Cambridge: Cambridge University Press, 1995). 
As a hugely complex 'site of memory', the First World War is an essential focus point of both European and national collective remembrance and of historical meaning, attracting intense attention from those involved in remembering and constantly being invested with new meaning. ${ }^{7}$ Like other well-established sites of memory, it possesses a massive tradition or 'genealogy' of remediation ${ }^{8}$ across various modes of cultural memory, one of these being historiography. ${ }^{9}$ Indeed, the origins and causes of the First World War are among the most discussed historical problems of Europe's 2oth century.10

In Serbia, the First World War is a strongly established and hugely politicized site of memory. Indeed, Serbia's First World War history supplies abundant material for a heroic national narrative. Attacked in 1914 by a much stronger neighbouring Austro-Hungarian Empire, the Serbian army successfully defended the country's borders until the winter of $1915^{-1916}$ when, overpowered by the joint offensive from Germany, Bulgaria and Austria-Hungary, the army retreated together with the Serbian government and the royal house through the mountains of Albania, abandoning Serbia to be occupied by the Central Powers. When they reached the Adriatic coast, Serbia's military forces were sailed to Corfu, where they were reorganized in order to be deployed as part of the Entente forces at the Salonica front. Here they contributed to the break-through of the Bulgarian lines of defence and the reconquering of Serbia, returning to Belgrade in October 1918. Serbia thus emerged as a victorious

7 On the concept of site of memory, see Ann Rigney, "Plenitude, scarcity and the circulation of cultural memory," Journal of European Studies 35, 1 (2005): 18. See also the description by Nora, who originally coined the phrase: Pierre Nora, "Between Memory and History: Les Lieux de Mémoire," Representations 26 (1989): 7-24.

8 Astrid Erll and Ann Rigney, "Introduction: Cultural Memory and its Dynamics," in $\mathrm{Me}$ diation, Remediation and the Dynamic of Cultural Memory, edited by Astrid Erll and Ann Rigney (Berlin/New York: De Gruyter, 2009), 5.

As Astrid Erll has pointed out, history may well be seen as "yet another mode of cultural memory" with historiography as its specific medium. Astrid Erll, "Cultural Memory Studies: An introduction," in A Companion to Cultural Memory Studies, edited by Astrid Erll and Ansgar Nünning (Berlin/New York: De Gruyter, 2010), 7.

For overviews of these discussions, see e.g. James Joll and Garton Martel, The Origins of the First World War, 3rd edition, (London: Routledge, 2007). For overviews of the wave of new studies published around the centenary of the war, see e.g. Hew Strachan, "Review article: The origins of the First World War," International Affairs 90, 2 (2014): 429-439; Andrew G. Bonnell, "New Histories of the Origins of the First World War: What happened to the 'Primacy of Domestic Politics'?" Australian Journal of Politics and History 61, 1 (2015): 121-127; William Mulligan, "Review-Article: The Trail Continues: New directions in the Study of the Origins of the First World War," English Historical Review 129, no. 538 (2014): $639-666$. 
Entente ally and played a dominant role in the creation of a new large South Slav state in 1918, when the Kingdom of Serbs, Croats and Slovenes (Yugoslavia from 1929) was established through a unification of the kingdoms of Serbia and Montenegro with the formerly Austro-Hungarian regions of Slovenia, Croatia and Bosnia. Yet, the costs of this uncompromising war effort were terrible; presumably a quarter of Serbia's pre-war population was killed fighting or died from war-related hunger or epidemics in the trenches or back home in the occupied country.11

The heroism and suffering of Serbia's army became key elements of the national mythology in the new Kingdom. Serbia's fallen soldiers on the allied side were widely commemorated with enthusiastic support, both personally and materially, from the Serbian royal house. ${ }^{12}$ From its very outset, Serbia regarded the Great War as a defensive struggle against the imperial ambitions of Austria-Hungary in the Balkans. 'Brave little Serbia', as the story went, was heroically defending its freedom against a manifold larger and stronger foe, and despite innumerable hardships it managed to survive and even triumph over the invading forces. This narrative was elaborated and institutionalized after the end of the war, becoming the official narrative of the newly formed Kingdom of Serbs, Croats and Slovenes (later called the Kingdom of Yugoslavia). ${ }^{13}$ It was during the first post-war years that several elements of the narrative template of Serbian First World War memory were first put in place: the brave, little state defending itself against the aggressions of the Austro-Hungarian Empire and managing to win spectacular victories, the suffering and patient nation, living through occupation and the terrible Albanian winter as the army

11 For an overview of Serbia's war history, see Andrej Mitrović, Serbia's Great War (London: Hurst, 2007); John R. Lampe, Yugoslavia as History. Twice there was a country (Cambridge: Cambridge University Press, 2000), 101-117; Stevan K. Pavlowitch, Serbia. The History behind the Name (London: Hurst, 2002), 93-110.

12 John Paul Newman, Yugoslavia in the Shadow of War. Veterans and the limits of State Building 1903-1945 (Cambridge: Cambridge University Press, 2015), 69; John Paul Newman, "Allied Yugoslavia: Serbian Great War Veterans and their Internationalist Ties," in The Great War and Veterans' Internationalism, edited by Julia Eichernberg and John Paul Newman (Basingstoke: Palgrave Macmillan, 2013), 110-112.

13 Danilo Šarenac, Top, Vojnik i Sećanje, Prvi Svetski Rat i Srbija 1914-20oo (Belgrade: Institut za savremenu istorju, 2014), 178-240; Olga Manojlović Pintar, Arheologija sećanje. Spomenici i identiteti i Srbiji 1918-1989 (Belgrade: Čigoja, 2014), 134-142; Ismar Dedović and Tea Sindbæk Andersen, "To Battle, go forth all heroes'. World War I Memory as a Narrative Template in Yugoslavia and Serbia," in Re-visting World War I. Interpretations and Perspectives of the Great Conflict, edited by Jaroslaw Suchoples and Stephane James (Frankfurt am Main: Peter Lang, 2016), 247-270. 
retreated to safety in Greece, and finally, the resurrection of the nation and the state as the Serbian army broke out from the front at Thessaloniki and liberated its country from Austria-Hungary and other occupiers. ${ }^{14}$

This narrative has, with modifications, dominated the perceptions of the Great War in Serbia and Yugoslavia since its establishment. Always focused primarily on the heroic Serbian side of wartime history, the narrative tended to exclude the memories of the millions of Yugoslav citizens who had experienced the war from within the Austro-Hungarian Empire or had fought in the Empire's armies. ${ }^{15}$ Yet, in spite of the strongly pro-Serbian leaning, efforts were made in the interwar Kingdom of Yugoslavia to create a more inclusive all-Yugoslav line of commemoration, for example by letting school book narratives emphasize the Yugoslav aspirations of Serbia's war effort or by constructing pro-Yugoslav monuments, such as the Monument to the Unknown Hero on mount Avala outside Belgrade. ${ }^{16}$

At the same time, the new state elevated Gavrilo Princip and his fellow conspirators to the status of national heroes and heralds of freedom for the South Slavs. This was a paradoxical move as it opened the state to international criticism for glorifying an assassin that - in the eyes of the world - put in motion a process leading to the Great War. ${ }^{17}$ But the Princip cult was at the same time a very potent symbol of the struggle of the South Slavs for their freedom. The graves of Princip and his fellows became sites of pilgrimage for young nationalists and in 1930 a memorial plaque was erected on the site of the assassination. ${ }^{18}$

14 See for example: Vladimir Ćorović, Istorija Jugoslavije (Belgrade: Narodno Delo, 1933), 6o9-618; Z. Špoljar, Povijest Hrvata, Srba i Slovenca za mladež nar. Osnovnih škola (Zagreb: Vlastita Naklada, 1927), 61-62; Dragan M. Adamović, Istorija Jugoslovena za podoficire (Zagreb: Merkantile, 1938), 137-145; Milan A. Kostić \& Mat P. Ljujić, Istorija Jugoslovena (Srba, Hrvata i Slovenaca) sa učenike II razreda osnovnih škola u Kraljevini Jugoslaviji (Belgrade: Knjižarnice Milorada P. Mihailovića, 1939), 42-43.

15 Newman, Yugoslavia in the Shadow of War; Dedović and Sindbæk Andersen, "'To Battle, go forth all heroes"'.

16 On Avala, see for example: Aleksandar Ignjatović, "From Constructed Memory to Imagined National Tradition: The Tomb of the Unknown Yugoslav Soldier (1934-38)," Slavonic and East European Review 88, 4 (2010): 624-651.

17 Paul B. Miller, "Compromising Memory: The Site of the Sarajevo Assassination," (Meeting Report 333, Woodrow Wilson Centre, Ees Noon Discussion, Sarajevo, 10 January 2007), accessed 8 August 2016, https://www.wilsoncenter.org/ publication/333-compromising-memory-the-site-the-sarajevo-assassination.

18 Muharem Bazdulj and Nebojsa Grujičić, eds., Stogodišnji rat. Sarajevskiatentat itumačenja (Beograd: Vreme, 2014), 45-47 and Selma Harrington, "The Politics of Memory: The Face and the Place of the Sarajevo Assassination," Prilozi, 43 (2014): 123. 
With the establishment of communist rule in Yugoslavia in 1945, commemoration of the Second World War, which had brought the Communist party to power, completely dominated public memory. Yet, in the background, the established memory narratives of the First World War remained, with history books and textbooks still focusing on Serbian heroism and suffering, only with a Marxist interpretation added, presenting the war as a result of the imperialist politics of Europe's great powers. ${ }^{19}$ In the socialist period, the cult of Gavrilo Princip was strengthened and received substantial official support. The Princip of the Communists became a revolutionary hero, struggling for national freedom and social justice. ${ }^{20}$

First World War memory attracted more attention in Yugoslavia after the 50 years anniversary of the War's outbreak in 1964, when new monuments were erected. ${ }^{21}$ Especially during the so-called 'outburst of history' in the 1980s, the Great War once again became an important and also controversial topic, particularly in Serbia. ${ }^{22}$ One of the strongest Serbian reassessments of First World War memory figured in Danko Popovićs hugely popular short novel The book about Milutin, which was published in 1985 . Milutin, a Serbian peasant who is being mobilized for the Serbian army, hears of the murder of Franz Ferdinand and is less than impressed: 'It is easy to kill a prince and a woman, but a war is not won by killing a prince and a wife' he thinks, wondering why Serbian peasants have to pay for this, and who will help Serbia, while the country's soldiers are fighting for the South Slavs. ${ }^{23}$ Popović thus lets Milutin undermine the heroic interpretation of Gavrilo Pincip and his fellow conspirators, and then moves on to underline the meaninglessness of the war and Serbia's huge sacrifices. In essence, Popović and other authors questioned the legitimacy and prudence in creating the common Yugoslav state, while emphasizing the suffering of Serbia for the Yugoslav cause. They also emphasized the futility of

19 See for example Ivan Božić et al., Istorija Jugoslavije (Belgrade: Prosveta, 1973), 380-397; Fuad Slipičević, Opšta i nacionalna istorija. Udžbenik za podoficire - pitomce vojnih akademija JNA (Belgrade, Kultura, 1968), 234-235; Šarlota Đuranović and Mirko Žeželj, Prošlost i sadašnjost 3. Udžbenik za vIII razred osnovne škole (Zagreb: Školska knjiga, 1974), 19. Husein Serdarević and Stanko Perazić Stanko, 8 Povijest. Udžbenik za viII razred osnovne škole (Sarajevo, Svjetlost 1977), 14.

Vera Katz, "Ideological use of Inauguration of Memorial Plaque Dedicated to Gavrilo Princip in the Raising and Education of Young Generations in BiH," Prilozi 37(2014): 99-111.

21 Olga Manojlović Pintar, "Tradicije Prvog Svetskog Rata u Srbiji," in Kultura Sjećanja 1918, edited by Tihomir Cipek \& Olivera Milosavljević (Zagreb: Disput, 2007), 159-162. Jasna Dragović-Soso, "Saviours of the Nation". Serbia's Intellectual Opposition and the Revival of Nationalism (London: Hurst, 2002), 77 and 89-100.

23 Danko Popović, Knjiga o Milutinu (Belgrade: Niro “Književne Novine”, 1986), 6. 
that sacrifice, since a majority of the other Yugoslav peoples seemed ungrateful to Serbia for liberating them in the Great War. In doing so, they rejected the Yugoslav aspect of Serbian First World War memory and paved the way for a narrowly national Serbian war memory. ${ }^{24}$

After the collapse of the Yugoslav state in 1991 the perception of the First World War in Serbia became increasingly nationalized. The country was still represented as an innocent victim, heroically defending its freedom against insurmountable odds, while the creation of the Yugoslav state was regarded as more of a problem than a positive outcome of the war.

\section{Rejecting Presumed Accusations}

It was this well-established and very national Serbian First World War memory that Tomislav Nikolić was defending in his letters and speeches in 2013 and 2014. Yet, Nikolić specifically felt the need to emphasize that Serbia could not be held responsible for the outbreak of the war. While this was at least partly a reaction to Christopher Clark's book, it still seems puzzling that the president himself must repeatedly use this somehow vague argument. However, President Nikolić was in fact repeating a pattern of discourse that can be traced back throughout Serbian (and Yugoslav) First World War history writing. As Astrid Erll has pointed out, 'existing representations which circulate in a given society provide schemata for new experience and its representation'. ${ }^{25}$ This kind of premediated schemata was one of the reasons behind Nikolić' reaction.

Since the end of the Great War, it has been an integral part of the Yugoslav (and later Serbian) memory tradition to present the war in a way that could absolve the country of the responsibility for the outbreak of war. From the establishment of the Yugoslav state, the defence against possible accusations of war guilt has taken the form of attempts to separate what were presented as the 'causes of war' from the actual 'pretext for war', the latter being the Sarajevo assassination. This rhetorical move has served to underline Serbia's innocence and justify Serbia's actions. There is a clearly distinctive 'genealogy of remediation'26 of that argument within Serbia's First World War memory.

\footnotetext{
24 See also Aleksandar Pavković, "The Serb National Idea: A Revival 1986-92," Slavonic and East European Review 72, 3 (1994), 3, 451-453; Dragović-Soso, "Saviours of the Nation", 89-100.

25 Erll, "Remembering across Time, Space and Culture," 111.

26 Erll and Rigney, 'Introduction: Cultural Memory and its Dynamics', p. 5 .
} 
According to history books from the interwar period, the causes for the war were to be sought in Austria. One book, a history teaching manual for junior officers, simply declared that 'the causes to the war lay in the great hatred that Austria felt towards Serbia.'27 History textbooks for primary and secondary school suggested that Austria-Hungary was worried by Serbia's expansion in the Balkan wars, and that the Empire wanted to prevent any further strengthening of the Serbian state. ${ }^{28}$ According to one of Serbia's leading historians in the interwar period, Vladimir Ćorović, Austria-Hungary feared a united Balkans dominated by Russia. Therefore leading circles in Vienna found that the only medicine for everything would be just to break Serbia. ${ }^{29}$ Yet, Austria needed an excuse - or a pretext - for attacking, and that was the assassination of Franz Ferdinand, even though Serbia could not at all, according to the books, be held responsible for that. A primary school textbook stated that: 'one day in the year 1914, without any just cause, Austria-Hungary declared war on little Serbia. As at that time on Vidovdan in Sarajevo the Austro-Hungarian heir to the throne was murdered by a young Serb from Bosnia, Gavrilo Princip, it [the Empire] declared that Serbs from Serbia were involved in this. And that was the pretext to declare war on Serbia. ${ }^{30}$ A secondary school textbook simply writes: 'To find an excuse for war, Austria-Hungary accused Serbia for the murder of their heir to the throne.31 And Ćorović emphasized how Austria 'without any proper documentation' accused Serbia itself for the murder of Franz Ferdinand, though Serbia was not involved. ${ }^{32}$

In history books from Yugoslavia's socialist era, this division into causes and pretexts remained clearly visible. It is present in history textbooks printed shortly after the end of the Second World War and it has been continuously remediated in various forms since then. Yet, during the socialist period this defensive rhetoric was given a different and more Marxist approach. The textbooks first present the international situation prior to the outbreak of war, emphasizing the colonial crises, the ambitions of the imperialist powers, the arms race and the inevitability of war owing to the logic of capitalism. Finally, Princip's assassination of Franz Ferdinand is presented as a mere pretext for

27 Adamović, Istorija Jugoslovena za podoficire, 136.

28 Špoljar, Povijest Hrvata, Srba i Slovenca, 61; Kostić \& Ljujić, Istorija Jugoslovena, 42; Lazarević, Istorija jugoslovena, 175.

29 Ćorović, Istorija Jugoslovije, 609.

30 Kostić \& Ljujić, Istorija Jugoslovena, 42. See also Adamović, Istorija Jugoslovea za podoficire, 137; Špoljar, Povijest Hrvata, Srba i Slovenca, 61; Ćorović, Istorija Jugoslavije, 610.

31 Lazarević, Istorija jugoslovena, 175.

32 Ćorović, Istorija Jugoslovije, 6o9-610. 
Germany or Austria-Hungary to start a war. ${ }^{33}$ An example of this is evident in an eighth grade history book from 1984. After presenting the numerous crises pre 1914, the text continues:

... the war was inevitable and both sides were putting enormous sums into armaments. Germany was the leading party in this and was just waiting for an opportune pretext to launch the war. The assassination on the Austro-Hungarian heir to the throne on 28 June 1914 was exactly this kind of opportunity. ${ }^{34}$

History books by socialist Yugoslavia's great historians also follow this pattern. Vladimir Dedijer, communist veteran from the Second World War and author of the official biography of President Tito, as well as several studies of the murder of Franz Ferdinand, wrote in 1973: 'Claiming that the Sarajevo assassination was the basic or immediate cause for the war would be an exaggeration ... the opposition between the European Great Powers were so tense, the reorganization and arming of the German armies had already reached such a level that only the smallest excuse was needed for the beginning of the conflict.'35 And according to Branko Petranovićs three-volume standard work on Yugoslav history, a war party in Vienna wanted to 'settle accounts with Serbia' and 'the murder of Archduke Franz Ferdinand gave the war party a pretext for war ...'36

All these books about the First World War clearly made an effort to emphasize that the outbreak of the war should certainly not be seen as something for which Serbia could be held responsible, as if to pre-empt any potential accusation against Serbia. One book, published for the $75^{\text {th }}$ anniversary of the Battle of Kolubara, where the hard-pressed Serbian armies successfully repelled an Austrian attack in November and December 1914, explicitly pointed to such accusations:

immediately after the assassination of Franz Ferdinand in Sarajevo ... an indictment was prepared against Serbia and the Serbian nation as

33 See for instance: Vojna akademija jugoslovenske armije, Katedra vojne istorije: Opšta vojna istorija: tekst. Sv. 2, Prvi svetski rat (Belgrade: Štamparija Vojne akademije jugoslovenske armije, 1950), 3-5; Đuranović and Žeželj, Prošlost i sadašnjost 3, 9; Tomo Čubelić and Dragutin Pavličević, Povijest XX. Stoljeća - sa odabranim povijesnim tekstovima. Udžbenik za stručne škole (Zagreb: Školska knjiga 1975), 9; Serdarević and Perazić, 8 Povijest, 14; Slipičević, Opšta i nacionalna istorija, 234-235.

34 Stanko Perazić and Husein Serdarević, Istorija - Povijest. Udžbenik za viıI razred osnovne škole (Sarajevo: Svjetlost, 1984), 7.

35 Božić et al., Istorija Jugoslavija, 374.

36 Branko Petranović, Istorija Jugoslavije 1918-1988. Prva Knjiga. Kraljevina Jugoslavije (Belgrade: Nolit, 1988), 7 . 
instigators of the war, and afterwards also the historical responsibility for the European (later called the World) War was loaded on their backs. Historical research has long ago established the actual responsibility for the war, but the old accusations, invented from the side of Serbia's enemies, are still talked about and appear to be fundamental. ${ }^{37}$

The authors remind their readers that a large amount of literature repeating these accusations is still present in the libraries and issue a warning: 'we must not forget that this was used as preparation for the attack on Yugoslavia in $1941 .{ }^{\prime 28}$ The authors thus underline how potentially dangerous such a war guilt could be, thereby actualizing the need to protect the Serbian version of First World War memory and to reject any possible blame.

These arguments were continuously remediated after the fall of Yugoslavia, still serving the purpose of removing the war guilt from Serbia. Almost all postYugoslav Serbian textbooks examined for this chapter repeat the pattern of those of the socialist period: On the first page(s) of the chapter on the Great War, a more or less detailed description of the world situation prior to 1914 is given, with an emphasis on the crises and conflicts of the Great Powers. A high school textbook from 2012 writes:

The causes of the outbreak of the First World War are to be found in the imperialist interests of the great European powers and their struggle for political and economic domination over the Old Continent at the end of the 19th and beginning of the 2oth Centuries. ${ }^{39}$

In this way, it is made explicitly clear that the Great Powers would have gone to war even if the assassination in Sarajevo had never happened. Thus, they largely copy the socialist argument, even though they do not use quite the same Marxist rhetoric anymore. ${ }^{40}$

37 Dušan T. Bataković and Nikola B. Popović, Kolubarska bitka (Belgrade: Biblioteka „Litera“, 1989), 5 .

38 Ibid.

39 Đorđe Đurić and Momčilo Pavlović, Istorija - za treći razred gimnazije prirodnomatematičkog smera i četvrti razred opšteg i društveno-jezičkog smera (Belgrade, Zavod za udžbenike, 2012), 72. See also Mira Radojević, Istorija - za treći razred gimnazije prirodnomatematičkog smera i četvrti razred opšteg i društveno-jezičkog smera i opsteg tipa i četvrti razred srednje stručne škole za obrazovne profile pravni tehničar i birotehničar (Belgrade: Klett, 2014), 86.

40 Only two of the textbooks do not fit this frame neatly: they place the cause of the war in the rivalry between Austria-Hungary and Serbia from 1903 to 1914 and the unresolved national questions of the Dual Monarchy, as well as Serbia's perceived desire to expand 
Just like in the Yugoslav period, the assassination itself is presented as a 'pretext for war'. Sometimes this is clear from the text itself while in other textbooks it is done in a headline that frames the understanding of the text in advance. ${ }^{41}$ Several textbooks also emphasize that Serbia had nothing to do with the assassination and therefore the Austro-Hungarian ultimatum was unreasonable. Clearly casting Serbia in the role of the victim, a high school textbook from 2012 states: 'Although the Serbian government was not responsible for the Sarajevo assassination, war circles in Vienna immediately launched a campaign, which accused the official Serbia of carrying it out. They reasoned that a war should be waged against a manifold weaker Serbia to defeat and humiliate it militarily.'42

The question of war guilt was thus being answered in a very uniform manner in Serbia. The fact that all textbooks use the same language, pointing to 'cause' versus 'pretext' when describing the run up to the war and that all have the same basic argumentative structure in their chapters on the Great War is indicative of a broader and strongly premediated memory tradition. Indeed, this had been the language and argumentative structure of Serbia's First World War memory scheme for nearly a century by the time Christopher Clark's book shook the Serbian public opinion and prompted President Nikolić to react.

\section{Clark and Nikolić}

Christopher Clark wrote in The Sleepwalkers that 'Since Srebrenica and the siege of Sarajevo, it has become harder to think of Serbia as the mere object or victim of great power politics and easier to conceive of Serbian nationalism as

its territory to include all lands in which Serbs or South Slavs lived. It should be noted that these two textbooks, although published a few years apart and for different audiences, were written by the same pair of authors, making their view all the more a minority one among the authors of modern textbooks in Serbia. There is no question of the authors implying Serbian responsibility for the war itself. Rather, the text should probably be understood as an indictment of Austro-Hungarian aggression against Serbia. See Radoš Ljušić and Ljubodrag Dimić, Istorija 8 - udžbenik za osmi razred osnovne škole sa čitankom i radnom sveskom (Belgrade: Freska, 2012), 72 ; Radoš Ljušić and Ljubodrag Dimić, Istorija - za treći razred gimnazije prirodno-matematičkog smera i četvrti razred opšteg i društvenojezičkog smera (Belgrade: Freska, 2014), 64.

41 Radojević, Istorija - za treći razred gimnazije, 86-87.

42 Đurić and Pavlović, Istorija - za treći razred gimnazije, 73. See also: Predrag M. Bajagić and Stošić, Nenad, Istorija 8 - udžbenik za osmi razred osnovne škole (Belgrade: Klett, 2011), 74; Predrag Simić and Ivana Petrović, Istorija 8 - udžbenik za osmi razred osnovne škole sa tematskim istorijskim atlasom (Belgrade: Logos, 2016), 62. 
an historical force in its own right ... Putting Sarajevo and the Balkans back at the centre of the story does not mean demonizing the Serbs or their statesmen, nor does it dispense us from the obligation to understand the forces working on and in those Serbian politicians, officers and activists whose behaviour and decisions helped to determine what kind of consequences the shooting at Sarajevo would have.43 Thus, he certainly pointed towards Serbia in his attempt to explain the outbreak of the First World War, suggesting that both the assassins and Serbia's politicians were at least partly responsible. Moreover, Clark explicitly argued that for Austria-Hungary 'the Sarajevo murders were not a pretext for a pre-existing policy of invasion and warfare. They were a transformative event, charged with real and symbolic menace. ${ }^{44}$ Knowingly or not, Clark thus directly rejected the essential elements of Serbia's narrative of innocence, which was based on the claim that the assassination was exactly not a cause, but a mere pretext. Furthermore, Clark suggested that Serbia's heroic fighting and status as belonging within the victorious camp of the Entente had somehow prevented Western historians from looking seriously at Serbia's role in the crisis that led to the First World War, and only the infamous events during the Yugoslav wars 1991-1995 had enabled them to look critically at Serbian nationalism. While he refused to ascribe guilt to any one side, but rather located parts of the guilt with every major player in the crisis, ${ }^{45}$ Clark could hardly have made a more direct attack on Serbian First World War memory and Serbian nationalism.

In Serbia, Clark's book was met with a response which far surpassed that of any other country. Not surprisingly, this was primarily a reaction to the parts of The Sleepwalkers that concentrated on Serbia's role in both the Sarajevo assassination and in the breakout of war in general. While these analyses and conclusions were considered the methodologically and theoretically weakest parts of the book, Serbian academic circles denounced the whole study as unscientific and lacking scholarly weight, while Serbian pundits and politicians regarded the work as not only lacking in merit, but as an attack on Serbia and its sacrifices during the Great War. ${ }^{46}$

Yet, the most clear and elaborate public reaction to the arguments in Clark's The Sleepwalkers came from Serbia's president, Tomislav Nikolić. Indeed, as was

43 Christopher Clark, The Sleepwalkers. How Europe Went to War in 1914 (London: Penguin 2013), xxvi-xxvii. The book was first published by Allen Lane in 2012. It was published in Serbian in 2013 .

44 Clark, The Sleepwalkers, 559.

45 Ibid, $560-561$.

46 See for instance: Danilo Šarenac, "O knjizi Mesečari. Kako je Evropa ušla u rat 1914, profesora Kristofera Klarka," Vojnoistorijski glasnik (2013), 1: 267-280 ; Milica Jovanović, "Sukob oko velikog rata," Peščanik 10 November 2013, accessed 10 November 2016, http://pescanik. net/sukob-oko-velikog-rata/. 
already obvious from his open letter to the newspaper Politika in November 2013, Nikolić had casted himself as defender of Serbia's First World War memory. ${ }^{47}$ On 10 November 2013, just before Armistice Day, Nikolić was also present at the reburial of Serbia's famous female First World War veteran, Milunka Savić, in Belgrade. Having briefly described Savić's life and praised her courage in the Second Balkan War and the First World War, the President compared the heroine to Serbia, as being both thoroughly good, but unappreciated and misunderstood: 'Milunka Savić so resembles her country. Courageous when needed, invincible and upright, ready to help everyone, but again pushed aside when others think that she might get in the way, being so great and strong.' Indeed, according to Nikolić, Savić was a 'symbol of Serbia's struggle for freedom."48 Thus, in Nikolićs narrative, Serbia's war history was, like Savić's, pure, brave and righteous.

In June 2014, just before the centenary, the Serbian Academy for Science and Arts (SANU) organized a conference on 'Serbs and the First World War'. Speaking as a guest of honour, Nikolić summarized the significance of that war for Serbia: 'A small, brave, country entered into a just fight for freedom, by the Grace of God it achieved victories, survived a Golgotha and, like Nathalie's ramonde under a drop of rain, it rose from the ashes and was revived' 49 This is a distilled version of the official Serbian representation of the First World War and as such it is not in any way surprising to find it repeated in the Presidential address. But the real aim of Nikolićs speech was not to repeat the official Serbian narrative, but rather to reaffirm and defend it against a perceived new threat. According to Nikolić, Serbs were confronted with an 'attempt at falsification of history in relation to the causes of the breakout of the First World War'. This falsification was driven by 'individuals from the echelon of the powerful' who would 'take facts out of context, twist them, alter their meaning, dress them in a new attire and give them a new look whereby a lie will become a globally accepted truth'.50 And, Nikolić continued, this attempt at a historical revision was mainly

47 Nikolić, "budimo dostojni junačke prošlosti”.

48 "Govor Predsednika Republika na ukopu posmrtnih ostataka M. Savić u Aleji Velikana," Belgrade, 10 November 2013 (A print of the speech was kindly supplied at request from the press centre at the office of the President of the Republic of Serbia). See also E.V.N., "Milunka Savić: Nepobediva kao Srbija," Večernje novosti, 10 November 2013, accessed 10 October 2016, http://www.novosti.rs/vesti/naslovna/drustvo/aktuelno.29o.html:463025-Milunka-SavicNepobediva-kao-Srbija;"NikolićoheroiniMilunkiSavić;Njenživotjekaopričaizholivudskog filma," Blic, 10 November 2013, accessed 10 October 2016, http://www.blic.rs/vesti/drustvo/ nikolic-o-heroini-milunki-savic-njen-zivot-je-kao-prica-iz-holivudskog-filma/sonfi5y.

"Govor Predsednika Republike, sANU - Veliki Rat". Nathalie's ramonde, or Ramonda Nathaliae is a small purple flower named after Serbia's queen Natalija. It grows in the South of Serbia. Since 2012 it has been a symbol of Serbia's Armistice Day. Ibid. 
aimed at Serbia: 'The Serb struggle for freedom, which has for an entire century been a worldwide symbol of the fight for justice and truth, a great deed, is now to be dragged through the mud.' The aim of this revision, according to Nikolić, was 'to make the world believe that Serbs caused a war, which took 10,000.00o lives'. Later in his speech, President Nikolić pointed specifically to the work of Christopher Clark as the primary source of this revisionism:

'In his book, Professor Clark describes the Great Powers of the time as sleepwalkers who staggered into war, though they in fact did not wish that ... Clark even connects the assassination in Sarajevo with the crime in Srebrenica in 1995, and because of that he says it is difficult for him to see Serbia as a victim! Luckily, there is a minimal number of such extremes within science or, rather, quasi science. Nobody, and really nobody serious, accuses Serbia of being the cause of the Great War ... Serbia entered the war to survive. It entered the war because there was no alternative. ${ }^{51}$

The fact that a scholarly work is interpreted as an attack on a sovereign country is to an extent puzzling and requires further examination. The first point to note here is that President Nikolić seemingly does not understand the nature of historical research. In his speech he states that 'After the publication of the book by the famous German historian, Fritz Fischer, it was believed that the question of war guilt was finally solved. ${ }^{52}$ It seems that Nikolic does not quite understand that historical questions - especially more complex ones such as the causes of the Great War - are rarely answered once and for all and that, for this reason, it is to be expected that historians will use an opportunity like the Centennial to once more bring up this theme.

The outrage levelled against Clark's work does not seem to have the character of a mere historical argument. The emotional appeals in Nikolić's reaction are very much about the present: he talks about lies and falsifications that take place in the current moment, and he fears that Serbia's great sacrifices are now to be 'dragged through the mud'. Clark's own rather un-historical connection between the Srebrenica massacre and Serbia's role in the events leading up to the First World War obviously touches a sore point and makes his argument even more unacceptable to Nikolić, who represents a state that still finds it difficult to recognize that massacre and admit to Serbia's co-responsibility for it, and the role that Serbian forces played in it. This makes Clark's parallel particularly problematic, as it constitutes a double accusation against Serbian nationalism,

$\begin{array}{ll}5^{1} & \text { Ibid. } \\ 5^{2} & \text { Ibid. }\end{array}$


both of which Nikolić denies. What really provokes Nikolić is the suggestion that, because of Srebrenica, Serbian nationalism is no longer innocent, and thus Serbia's status as a righteous victim in the First World War is threatened.

It is unlikely that a President would address this topic if it were relevant to historians only. Indeed, Nikolić's speech was not an isolated act: in the run up to the centennial, numerous Serbian articles, op-eds etc. dealt with the issue of the outbreak of war in general and Clark's book in particular. By and large this media campaign expressed the same views as the President in his speech to members of SANU. ${ }^{53}$ Nikolićs speech thus seems to reflect and protect a dominant and widespread presentation of the Great War in Serbia. However, this does not necessarily explain why a president would chose to throw himself into the fray like Nikolić does. One explanation, suggested by the historian Dubravka Stojanović, is that the speech itself and the general debate on the war in Serbia was instrumentalized by the political elites in order to distract the populace from unpopular reforms and a faltering economy by whipping up nationalist frenzy. This would, furthermore, have the effect of signalling to nationalists in Serbia that the pro-EU course of the state was only a necessary evil while the real ambitions of Serbia were rooted in the nationalist framework and its history. ${ }^{54}$ One argument in favour of this explanation is that the First World War as a contested topic seemingly disappeared as soon as the main festivities and ceremonies were over.

53 E.g.: Zoran Radisavljević, "Gavrilo Princip je pucao u okupatora," Politika 20 September 2013, accessed 14 November 2016, http://www.politika.rs/scc/clanak/270687/GavriloPrincip-je-pucao-u-okupatora; D. Stanisić, "Kusturica: Gavrilo Princip je branio ideju slobode,", Politika 5 December 2013, accessed 14 November 2016, http://www.politika.rs/ sr/clanak/277735/Kusturica-Gavrilo-Princip-je-branio-ideju-slobode; Gradimir Aničić, "Princip nije fanatik", Politika, 10 June 2014, accessed 14 November 2016, http://www.politika.rs/sr/clanak/296051/принцип-није-фанатик.; Aleksandar Nikolić, "Srđan Koljević: Svakoj generaciji treba Princip," Blic, 29 June 2014, accessed 14 November 2016, http:// www.blic.rs/vesti/tema-dana/srdan-koljevic-svakoj-generaciji-treba-princip/sptvesc; Tatjana Nježić, "Legenda Gavrilo: Poznati srpski pisci odgovaraju na pitanje ko je bio Princip," Blic, 29 June accessed 14 November 2016, http://www.blic.rs/kultura/vesti/legenda-gavrilo-poznati-srpski-pisci-odgovaraju-na-pitanje-ko-je-bio-princip/4vn35xp; Miljana Leskovac, "Princip nije kriv za rat”, Blic, 1 June 2014, accessed 14 November 2016, http://www .blic.rs/vesti/drustvo/princip-nije-kriv-za-rat/5cvjtmt; Tanjug, "Dodik: Rs ne pristaje na politizaciju Prvog svetskog rata”, Blic, 11 June 2014, accessed 14 November 2016, http://www .blic.rs/vesti/politika/dodik-rs-ne-pristaje-na-politizaciju-prvog-svetskog-rata/g813qso.

"Ljudi iz šume," Interview with Dubravka Stojanović, Peščanik, 29 November 2013, accessed 14 November 2016 http://pescanik.net/ljudi-iz-sume/, and "Mitski rat," Interview with Dubravka Stojanović, Peščanik, 27 June 2014, accessed 14 November 2016 http://pescanik.net/emisija-27-06-2014/. 
However, this functional understanding does not quite explain why Nikolić and other parts of the Serbian public reacted so strongly to Clark's rethinking of the causes for the First World War, or indeed, why the First World War as such could become such a vital topic. Why this particular history? As has been shown in this chapter, the First World War is a well-established and very present memory in Serbia. The heroic and tragic narrative of Serbia's First World War is well known and certainly has the potential to be emotionally affective. Moreover, through the century that has passed since the war, Serbian (and Yugoslav) narratives have consequently rejected that Serbia could in any way be held responsible for the war's outbreak. And while Princip and his fellow assassins have been presented as heroes, their deed has never been accepted as a cause for the war; it was, in the Serbian phrase, only a pretext. Yet, Princip's heroic status is seemingly less important than Serbia's status as an innocent and heroic victim of the war. Indeed, given the catastrophic consequences of the First World War for Serbia, with the loss of about one quarter of the country's population, it would seriously question the legitimacy of Serbian nationalism and nationalist politics if exactly that nationalism were to be seen as the main cause of that war. Thus, Nikolic confirms the established narrative that Serbia was forced into the war, and thus he defends its status as an innocent victim of Great Power politics. As such, his reaction was highly premediated; indeed he repeated an argumentative scheme that was established in the interwar period and has been remediated in Serbian and Yugoslav history books ever since.

The repeated rejection that Serbia in any way could be held responsible for the outbreak of the war inevitably had the effect of suggesting that such an accusation could indeed be made. The defensive discourse created the understanding that there was a need for Serbia to defend itself. Thus, it actualized the memory of the First World War as something that had to be protected, rendering it with certain urgency. Indeed, President Nikolić's reaction to Clark's book did have the appearance of an urgent need to protect Serbia's national memory. Moreover, the established memory narrative portrays the victory in the First World War as decisive for Serbia's existence; in Nikolićs rhetoric it was an unavoidable Golgotha of the Serbian nation, a war that Serbia entered to survive. Thus, it is the memory of a fatal and definitive event that Nikolić had taken upon himself to defend.

\section{Conclusion}

The existence of Serbia's strong tradition of First World War memory and the pervasiveness of the 'anti-war guilt rhetoric' help explain the need of Nikolić 
and other parts of Serbia's elites to react strongly to Clark's shifting of the responsibility from Germany towards Serbia. Not only was he thereby challenging the established truth on the war in Serbia; he was also adding new weight to an idea that - however unspoken - has always been present in the textbooks: namely that Serbia will always be thought of as potentially responsible for the outbreak of the war. The defensive argument is necessary to disprove such accusations.

In his speeches and statements in the run-up to the centenary of the First World War, Serbia's President Nikolić clearly confirmed and remediated a wellestablished narrative and argumentative scheme of Serbian First World War memory. Yet, his statements were also clearly a reaction to the publication of Christopher Clark's rethinking of the causes to the First World War, and as such Nikolićs speeches and letters are probably the most public and political reception of Clark's book. Nikolić's response was highly premediated; in essence he was repeating the defensive arguments that had been present in Serbian and Yugoslav history books for nearly a century. Apparently, Nikolić perceived Clark's argument as if he was stating the accusations that the Serbian tradition had been rejecting since the end of the First World War. Indeed, the fact that Clark's book fitted so neatly into the fears and argumentative patterns of Serbia's First World War memory was probably the main reason why it attracted so much attention in Serbia.

\section{Bibliography}

Adamović, Dragan M. Istorija Jugoslovena za podoficire. Zagreb: Merkantile, 1938.

Aničić, Gradimir. "Princip nije fanatik." Politika, 10 June 2014. Accessed 14 November 2016. http://www.politika.rs/sr/clanak/296051/принцип-није-фанатик.

Bajagić, Predrag M. and Nenad Stošić. Istorija 8-udžbenik za osmi razred osnovne škole. Belgrade: Klett, 2011.

Bataković, Dušan T. and Nikola B. Popović. Kolubarska bitka. Belgrade: Biblioteka, Litera, 1989.

Bazdulj, Muharem and Nebojsa Grujičić, eds. Stogodišnji rat. Sarajevski atentat $i$ tumačenja. Beograd: Vreme, 2014.

Bonnell, Andrew G. "New Histories of the Origins of the First World War: What happened to the 'Primacy of Domestic Politics'?" Australian Journal of Politics and History, 61, 1 (2015): 121-127.

Božić, Ivan et al. Istorija Jugoslavije. Belgrade: Prosveta, 1973.

Clark, Christopher. The Sleepwalkers. How Europe Went to War in 1914. London: Penguin 2013. 
Ćorović, Vladimir. Istorija Jugoslavije. Belgrade: Narodno Delo, 1933.

Čubelić, Tomo and Dragutin Pavličević. Povijest XX. Stoljeća - sa odabranim povijesnim tekstovima. Udžbenik za stručne škole. Zagreb: Školska knjiga 1975.

Dedović, Ismar and Tea Sindbæk Andersen. "To Battle, go forth all heroes'. World War I Memory as a Narrative Template in Yugoslavia and Serbia." In Re-visting World War I. Interpretations and Perspectives of the Great Conflict, edited by Jaroslaw Suchoples and Stephane James, 247-270. Frankfurt am Main: Peter Lang, 2016.

Dragović-Soso, Jasna. "Saviours of the Nation". Serbia's Intellectual Opposition and the Revival of Nationalism. London: Hurst, 2002.

Đuranović, Šarlota and Mirko Žeželj. Prošlost i sadašnjost 3. Udžbenik za VIII razred osnovne škole. Zagreb: Školska knjiga, 1974.

Đurić, Đorđe and Momčilo Pavlović, Istorija - za treći razred gimnazije prirodnomatematičkog smera $i$ četvrti razred opšteg $i$ društveno-jezičkog smera. Belgrade, Zavod za udžbenike, 2012.

Erll, Astrid. "Remembering across Time, Space and Culture: Premediation, Remediation and the 'Indian Mutiny." In Mediation, Remediation and the Dynamic of Cultural Memory, edited by Astrid Erll and Ann Rigney, 109-138. Berlin: De Gruyter, 2009.

Erll, Astrid. "Cultural Memory Studies: An introduction." In A Companion to Cultural Memory Studies, edited by Astrid Erll and Ansgar Nünning, 1-15. Berlin/New York: De Gruyter, 2010.

Erll, Astrid and Ann Rigney. "Introduction: Cultural Memory and its Dynamics." In $M e-$ diation, Remediation and the Dynamic of Cultural Memory, edited by Astrid Erll and Ann Rigney, 1-11. Berlin/New York: De Gruyter, 2009.

E.V.N. "Milunka Savić: Nepobediva kao Srbija." Večernje novosti, 10 November 2013. Accessed 10 October 2016. http://www.novosti.rs/vesti/naslovna/drustvo/aktuelno.29o.html:463025-Milunka-Savic-Nepobediva-kao-Srbija.

"Govor Predsednika Republika na ukopu posmrtnih ostataka M. Savić u Aleji Velikana," Belgrade, 10 November 2013 (A print of the speech was kindly supplied at request from the press centre at the office of the President of the Republic of Serbia).

"Govor Predsednika Republike, SANU - Veliki Rat. 13 June 2014." (A print of the speech was kindly supplied at request from the press centre at the office of the President of the Republic of Serbia).

Harrington, Selma. "The Politics of Memory: The Face and the Place of the Sarajevo Assassination." Prilozi 43 (2014):113-139.

Ignjatović, Aleksandar. "From Constructed Memory to Imagined National Tradition: The Tomb of the Unknown Yugoslav Soldier (1934-38)." Slavonic and East European Review 88, 4 2010: 624-651.

Joll, James and Garton Martel. The Origins of the First World War. 3rd edition. London: Routledge 2007.

Jovanović, Milica. "Sukob oko velikog rata." Peščanik, 10 November 2013. Accessed 10 November 2016. http://pescanik.net/sukob-oko-velikog-rata/. 
Katz, Vera. "Ideological use of Inauguration of Memorial Plaque Dedicated to Gavrilo Princip in the Raising and Education of Young Generations in BiH." Prilozi 37 (2014): 99-111.

Kennan, George. The Decline of Bismarck's European Order. Franco-Russian relations, 1875-189o. Pinceton: Princeton University Press, 1979.

Kostić, Milan A. and Mat P. Ljujić. Istorija Jugoslovena (Srba, Hrvata i Slovenaca) sa učenike III razreda osnovnih škola u Kraljevini Jugoslaviji. Belgrade: Knjižarnice Milorada P. Mihailovića, 1939.

Lampe, John R. Yugoslavia as History. Twice there was a country. Cambridge: Cambridge University Press, 2000.

Leskovac, Miljana. "Princip nije kriv za rat." Blic, 1 June 2014. Accessed 14 November 2016. http://www.blic.rs/vesti/drustvo/princip-nije-kriv-za-rat/5cvjtmt.

"Ljudi iz šume," Interview with Dubravka Stojanović. Peščanik, 29 November 2013. Accessed 14 November 2016. http://pescanik.net/ljudi-iz-sume/.

Ljušić, Radoš and Ljubodrag Dimić. Istorija 8 - udžbenik za osmi razred osnovne škole sa čitankom i radnom sveskom. Belgrade: Freska, 2012.

Ljušić, Radoš and Ljubodrag Dimić. Istorija - za treći razred gimnazije prirodnomatematičkog smera i četvrti razred opšteg i društveno-jezičkog smera. Belgrade: Freska, 2014.

Manojlović Pintar, Olga. “Tradicije Prvog Svetskog Rata u Srbiji.” In Kultura Sjećanja 1918, edited by Tihomir Cipek and Olivera Milosavljević, 155-167. Zagreb: Disput, 2007 .

Manojlović Pintar, Olga. Arheologija sećanje. Spomenici i identiteti i Srbiji 1918-1989. Belgrade: Čigoja, 2014.

Miller, Paul B. "Compromising Memory: The Site of the Sarajevo Assassination." Meeting Report 333, Woodrow Wilson Centre, EEs Noon Discussion, Sarajevo, 10 January 2007. Accessed 14 November 2016. https://www.wilsoncenter.org/ publication/333-compromising-memory-the-site-the-sarajevo-assassination.

Mitrović, Andrej. Serbia's Great War. London: Hurst, 2007.

"Mitski rat," Interview with Dubravka Stojanović. Peščanik, 27 June 2014. Accessed 14 November 2016. http://pescanik.net/emisija-27-06-2014/.

Mosse, George L. Fallen Soldiers. Reshaping the Memory of the World Wars. Oxford: Oxford University Press, 1990.

Mulligan, William. "Review-Article: The Trail Continues: New directions in the Study of the Origins of the First World War." English Historical Review 129, 538 (2014): $639-666$.

Newman, John Paul. "Allied Yugoslavia: Serbian Great War Veterans and their Internationalist Ties." In The Great War and Veterans' Internationalism, edited by Julia Eichernberg and John Paul Newman, 97-117. Basingstoke: Palgrave Macmillan, 2013.

Newman, John Paul. Yugoslavia in the Shadow of War. Veterans and the limits of State Building 1903-1945. Cambridge: Cambridge University Press, 2015. 
Nikolić, Aleksandar. "Srđan Koljević: Svakoj generaciji treba Princip." Blic, 29 June 2014. Accessed 14 November 2016. http://www.blic.rs/vesti/tema-dana/ srdan-koljevic-svakoj-generaciji-treba-princip/sptvesc.

"Nikolić o heroini Milunki Savić; Njen život je kao priča iz holivudskog filma." Blic, 10 November 2013. Accessed 10 October 2016. http://www.blic.rs/vesti/drustvo/ nikolic-o-heroini-milunki-savic-njen-zivot-je-kao-prica-iz-holivudskog-filma/ sonfi5y.

Nikolić, Tomislav. "budimo dostojni junačke prošlosti." Politika, 10 November 2013. Accessed 15 September 2016. http://www.politika.rs/sr/clanak/275423/ Budimo-dostojni-junacke-proslosti.

Nježić, Tatjana. "Legenda Gavrilo: Poznati srpski pisci odgovaraju na pitanje ko je bio Princip." Blic, 29 June. Accessed 14 November 2016. http://www.blic.rs/kultura/vesti/legenda-gavrilo-poznati-srpski-pisci-odgovaraju-na-pitanje-ko-je-bioprincip/4vn35xp.

Nora, Pierre. "Between Memory and History: Les Lieux de Mémoire." Representations, 26 (1989): 7-24.

Pavković, Aleksandar. "The Serb National Idea: A Revival 1986-92." Slavonic and East European Review, 72, 3 (1994): 440-455.

Pavlowitch, Stevan K. Serbia. The History behind the Name. London: Hurst, 2002.

Perazić, Stanko and Husein Serdarević. Istorija- Povijest. Udžbenik za VIII razred osnovne škole. Sarajevo; Svjetlost, 1984.

Petranović, Branko. Istorija Jugoslavije 1918-1988. Prva Knjiga. Kraljevina Jugoslavije. Belgrade: Nolit, 1988.

Popović, Danko. Knjiga o Milutinu. Belgrade: Niro “Književne Novine”, 1986.

Radisavljević, Zoran. "Gavrilo Princip je pucao u okupatora." Politika 20 September 2013. Accessed 14 November 2016. http://www.politika.rs/scc/clanak/270687/ Gavrilo-Princip-je-pucao-u-okupatora.

Radojević, Mira. Istorija - za treći razred gimnazije prirodno-matematičkog smera $i$ četvrti razred opšteg i društveno-jezičkog smera i opsteg tipa i četvrti razred srednje stručne škole za obrazovne profile pravni tehničar i birotehničar. Belgrade: Klett, 2014.

Rigney, Ann. "Plenitude, scarcity and the circulation of cultural memory." Journal of European Studies 35, 1 (2005): 11-28.

Šarenac, Danilo. "O knjizi Mesečari. Kako je Evropa ušla u rat 1914, profesora Kristofera Klarka.” Vojnoistorijski glasnik (2013), 1: 267-280.

Šarenac, Danilo. Top, Vojnik i Sećanje, Prvi Svetski Rat i Srbija 1914-20oo. Belgrade: Institut za savremenu istorju, 2014.

Serdarević, Husein and Stanko Perazić Stanko. 8 Povijest. Udžbenik za VIII razred osnovne škole, Sarajevo, Svjetlost 1977.

Simić, Predrag and Ivana Petrović. Istorija 8 - udžbenik za osmi razred osnovne škole sa tematskim istorijskim atlasom. Belgrade: Logos, 2016. 
Slipičević, Fuad. Opšta i nacionalna istorija. Udžbenik za podoficire - pitomce vojnih akademija JNA. Belgrade: Kultura, 1968.

Špoljar, Z. Povijest Hrvata, Srba i Slovenca za mladež nar. Osnovnih škola. Zagreb: Vlastita Naklada, 1927.

Stanisić, D. “Kusturica: Gavrilo Princip je branio ideju slobode.” Politika 5 December 2013. Accessed 14 November 2016. http://www.politika.rs/sr/clanak/277735/KusturicaGavrilo-Princip-je-branio-ideju-slobode.

Strachan, Hew. "Review article: The origins of the First World War." International Affairs, 90, 2 (2014): 429-439.

Tanjug. "Dodik: Rs ne pristaje na politizaciju Prvog svetskog rata." Blic, 11 June 2014. Accessed 14 November 2016. http://www.blic.rs/vesti/politika/dodik-rs-ne-pristajena-politizaciju-prvog-svetskog-rata/g813qso.

Vojna akademija jugoslovenske armije, Katedra vojne istorije: Opšta vojna istorija: tekst. Sv. 2, Prvi svetski rat. Belgrade: Štamparija Vojne akademije jugoslovenske armije, 1950.

Winter, Jay. Sites of Memory, Sites of Mourning. The Great War in European Cultural History. Cambridge: Cambridge University Press, 1995. 